\title{
MICROBIAL DIVERSITY AND PHYLOGENETIC STUDIES OF SOME MICROBES OBTAINED FROM UNEXPLORED CAVES OF SAUDI ARABIA
}

\author{
Reda Hassan Amasha*
}

King Abdulaziz University, Faculty of Science, Department of Biology, Jeddah, Saudi Arabia, P.O Box: 42799 Jeddah 21551 Saudi Arabia

Received - January 14, 2018; Revision - March 20, 2018; Accepted - April 13, 2018

Available Online - April 25, 2018

DOI: http://dx.doi.org/10.18006/2018.6(2).342.351

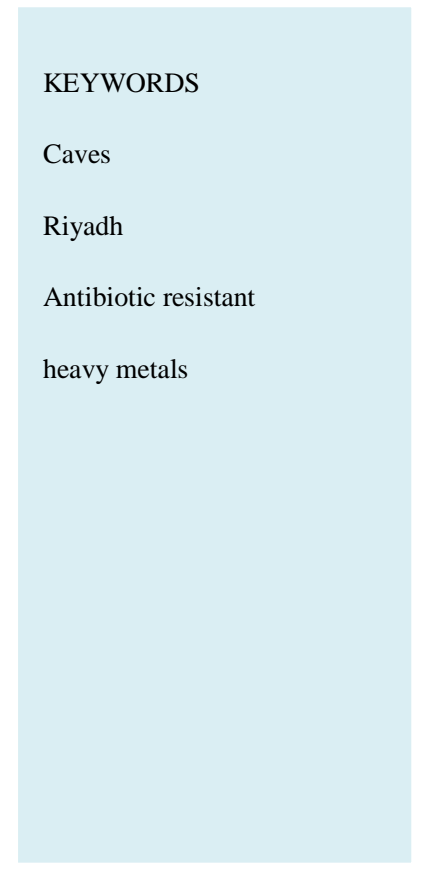

\begin{abstract}
The microbial diversity within cave ecosystems is largely unknown. This study aimed to studying the microbial communities of the three caves viz Mossy, Hotel and Reda caves which are located approximately 200 km of Riyadh region, between Riyadh and Al Kharj road, Saudi Arabia. These caves have an intricate cave system which developed in the calcareous sandstone and clay. Morphological interpretation revealed that Mossy cave was different from Hotel and Reda caves where it is tall and have a linear cave passage and narrow canyons. Various field studies revealed that many bacteria inhibited in caves and obtained their energy from degradation of inorganic substances, thus they directly interact with the surfaces where they live on. In present study, soil and wall dust samples were collected and cultured on Nutrient agar, starch nitrate agar and PDA plates. During study various Gram positive, Gram negative bacteria, actinomycetes and fungi were isolated from the cave soil and wall. The isolated bacteria were characterized and identified by using culture-dependent methods (morphological and physiological methods). Identifications of the most occurring bacterial genera were confirmed by using $16 \mathrm{~S}$ rRNA gene amplicon sequencing which revealed the presence of 11 broad taxonomic species of bacteria. Among these, Proteobacteria were dominant in all caves and this was followed by Actinobacteria, Firmicutes and Bacteroidetes. Majority of the true bacterial isolates belong to the genera Alcaligenes, Bacillus, Brevibacterium, Klebsiella, Planomicrobium, Shigella, Pseudomonas and Staphylococcus. During study, percentage of resistance to some metallic cations, heavy metals and antibiotics were also determined. Result of study revealed that Bacillus cereus, Klebsiella pneumoniae
\end{abstract}

* Corresponding author

E-mail: ramashah@kau.edu.sa (Reda Hassan Amasha)

Peer review under responsibility of Journal of Experimental Biology and Agricultural Sciences.

Production and Hosting by Horizon Publisher India [HPI] (http://www.horizonpublisherindia.in/).

All rights reserved.
All the article published by Journal of Experimental Biology and Agricultural Sciences is licensed under a Creative Commons Attribution-NonCommercial 4.0 International License Based on a work at www.jebas.org. 
and Pseudomonas earuginosa showed the highest resistant percentage to the tested heavy metals while Pseudomonas earuginosa, Klebsiella pneumoniae and Staphylococcus aureus were the highest resistant to the tested antibiotics. In conclusion, present study provide beneficial information about microbial diversity, taxonomic and their resistance to some heavy metals and antimicrobial agents in three uncharacterized caves, located in Alsoman region, north east of Riyadh.

\section{Introduction}

All imaginable environment including unexplored caves must be examined for new microorganisms (Barton \& Luiszer, 2005). Saudi Arabia is a country with rarest wild caves with interesting and popular geologic and geomorphic features. Its caves have great exploration potential with unsurpassed beauty that provides unending curiosity to a caver. Jabal Al Qarah Cave is located between Dammam and Al-Hofuf, Saudi Arabia and its cool protected passages and considered a gathering place for visitation (Hotzl et al., 1978, Hussain et al., 2006). Harrat Khaybar lava caves, Dahl Rumahah, Kahf Al Shuwaymis, and Umm Jirsan Lava-Tube are some of the oldest caves which explored for their ecology and diversity in Saudi Arabia (Pint, 2009). Very few geological studies have been carried out about the caves located in Saudi Arabia (Forti et al., 2003; Al-Shanti et al., 2003). Microorganisms interact directly with the geology of our planet and their activities have provided the oil, oxygen and the essential nutrients such as carbon, nitrogen and phosphorus. Cave microbiology deals with microorganisms that are found in caves and have the ability to consume inorganic material for energy and survive under extreme conditions (Madigan et al., 2000, Shivaji et al., 2004). Extreme conditions included physical and chemical environmental limits, high temperatures, acid conditions, low light and growth under salt stress (Hathway, 2010). Generally, microorganisms from caves have been considered extreme microbes, because of their ability to grow at low nutrient accessibility, low or high temperature and moderately high humidity, under minimum light conditions of caves (Hathway, 2010). Attempts must be carried out to understand the difficulties associated with microbial activities in cave environments. The significant roles of cavers are the identification of new cave biota and conserving the microbial habitats of caves. Traditional methods such as growing microorganisms in Petri plates, Gram staining, type of respiration and mode of motion are generally used for bacterial identification but unfortunately if the number of bacterial species are higher than 5,000/gram, it is difficult to identify by above said technique (Amann et al., 1966). Thus, recently methods based on genetic sequences (16S rRNA gene) were used to identify and determine the diversity of the isolated bacteria (Al'Abri, 2011; Amasha, 2012, Almalki, 2012). Very little information is available about the diversity and importance of cave microbes, thus further researches on caves microbiology are needed. Moreover, the biodiversity of bacteria in Saudi Arabian caves are not received scientific attentions (Pint, 2006) and available published literature about the geology of the Saudi Arabian caves and their biological composition are in scarcity (Forti et al., 2003, Al-Shanti et al., 2003). There are several caves that have not been explored yet for their geomorphology and microbial diversity. This study aimed at studying and determining bacterial diversity of three caves viz. Mossy, Hotel and Reda caves near Riyadh, Saudi Arabia.

\section{Material and methods}

\subsection{Study area:}

Three easily accessible caves in the vicinity of Riyadh named, Mossy Cave: $26^{\circ} 27^{\prime} 33.2^{\prime \prime} \mathrm{N}, 4^{\circ} 14^{\prime} 03.3^{\prime \prime} \mathrm{E}$, Hotel cave: $26^{\circ} 28^{\prime}$ $14.247^{\circ} 14^{\prime} 23.8^{\prime \prime} \mathrm{E}^{\prime \prime}$, and Reda cave: $26^{\circ} 27^{\prime} 10.5^{\prime \prime} \mathrm{N}, 47^{\circ} 15^{\prime} 1.9^{\prime \prime} \mathrm{E}$ were visited with the help of a local cave explorer (Dr. Mahmoud Ahmed Shanti, Saudi geological Survey). All three caves are located in Somman area and the visitation was low because these were not opened for visitors. During the study period, the average temperature ranged from $11^{\circ} \mathrm{C}$ (January) to $43^{\circ} \mathrm{C}$ (July and August). Representative photos were taken for each cave and all samples were photo-documented at the collection area. Elevation of the cave (m) at the entrance, temperature, humidity and RH were determined during January 2017. Relative humidity is approximately the ratio of the actual to the saturation vapour pressure and is calculated from the following equation

$\mathrm{RH}=($ Actual vapor pressure $) /($ Saturation vapor pressure $) \times 100 \%$

\subsection{Sample collocation}

From each cave, ten soil samples were collected from surface soils and cave walls (microbial mats) from the entire selected cave by following protocol of Amasha (2012). All the collected samples were taken in sterile containers with a sterilized spoon and brought to the Laboratory of Microbiology, University of King Abdulaziz, Jeddah, Saudi Arabia for further analysis. All soil samples were spread on a clean paper sheet until dries.

\subsection{Soil analysis}

Analysis of chromium $(\mathrm{Cr})$, cadmium $(\mathrm{Cd})$, cobalt $(\mathrm{Co})$, copper $(\mathrm{Cu})$ and iron $(\mathrm{Fe})$ in each soil sample was carried out. All 
samples were homogenized; particle size, distribution and organic carbon (Org. C) content were determined using the loss-ofignition method (Donkin 1991) and sieving method (Laker \& Dupreez, 1982), respectively. The $\mathrm{pH}$ value was measured in soil extract $(1: 2 \mathrm{w} / \mathrm{v})$ by the method of Sonneveld \& Van Den Ende (1971). Soil sample digestion was carried by $10 \mathrm{~N}$ of mixture of ultrapure nitric acid $\left(\mathrm{HNO}_{3}\right)$ and $\mathrm{HCl}$. Metal detection was determined using Agilent 7500 Capillary Electrophoresis series Inductively Coupled Plasma Mass Spectrometer. Geoaccumulation index was calculated from the relation (Muller, 1969; Loska et al., 2004; Ji et al., 2008):

\section{I geo $=\log 2 \mathrm{Cn} / 1.5 \mathrm{Bn} \quad$ (du Preez et al., 2016)}

$\mathrm{C}_{\mathrm{n}}$ : measured concentration of $\mathrm{n}$ (element), $\mathrm{B}_{\mathrm{n}}$ : measured geochemical background value.

\subsection{Microorganism's isolation and total microbial count}

One gram of each sample was suspended in $10 \mathrm{ml}$ sterile distilled water and serial dilution carried out. From the suitable dilution, bacteria, actinomycetes and fungi were isolated on nutrient agar, starch nitrate agar (Pridham et al., 1957) and PDA, respectively. After 2 days of incubation at $37^{\circ} \mathrm{C}$ for bacteria and 7 days of incubation at $25^{\circ} \mathrm{C}$ for actinomycetes and fungi, colonies were counted, selected and streaked on new agar plates until pure colonies were obtained. Total bacterial, fugal and actinomycetes counts for different collected samples were determined using agar plate count methods. All pure colonies were preserved on agar slants of the same medium at $4^{\circ} \mathrm{C}$ until used.

\subsection{Bacterial identification}

\subsubsection{Morphological and physiological characteristics}

Isolated bacteria were identified on the basis of various morphological characteristics such as Gram stain, cell shape, colony characteristics and growth on different nutrient media in addition to physiological characters like production of catalase, oxidase, gelatinase, chitinase and amylase (Plotnikova et al., 2010). For Gram negative bacteria, biochemical reactions were carried out using API20E system (Bio Mérieux S.A, France).

\subsubsection{Molecular identification}

16SrRNA sequencing was used to identify bacteria from caves sample. Genomic DNA was extracted from isolated and purified bacterial isolates and then PCR was used with the appropriate primers to produce large quantities of the 16SrRNA gene (Al'Abri, 2011). Phylogenetic grouping was performed using a multiplex PCR-based assay as described by Clermont et al. (2000). During molecular identification, the name and sequence of the used premiers have been given in Table 1. 16S rRNA gene was amplified using $10 \mathrm{p} \mathrm{mol} / \mu \mathrm{l}$ of each forward $785 \mathrm{~F}$ (5'- GGA TTA GAT ACC CTG GTA -3') and reverse 907R (5'- CCG TCA ATT CMT TTR AGT TT-3'). DNA extraction, PCR and sequencing were carried out at Macrogen, Geumcheon-gu, Seoul 08511, Republic of Korea.

Table 1 Premiers name and sequences used in this study.

\begin{tabular}{cc} 
Name of Premiers & Premiers sequences \\
\hline 785 F5' & (GGA TTA GAT ACC CTG GTA)3 \\
\hline 907R5' & (CCG TCA ATT CMT TTR AGT TT) 3' \\
\hline $27 F 5 '$ & (AGA GTT TGA TCM TGG CTC AG) 3 \\
\hline '1492R 5 & '(TAC GGY TAC CTT GTT ACG ACT T) 3' \\
\hline
\end{tabular}

\subsubsection{Metal tolerance and antibiotic resistance patterns}

All the obtained bacterial isolates were screened for resistance to heavy metals $(1300 \mu \mathrm{g} / \mathrm{ml}), \mathrm{Cu}, \mathrm{Cd}$ and $\mathrm{Cr}$ using agar dilution method. After $24 \mathrm{hr}$ of incubation, the plates were examined for bacterial growth (Washington \& Sutter, 1980). Antibiotic resistance of the differed bacterial isolates were determined by standard disc diffusion method (Finegold \& Martin, 1982) on Mueiler-Hinton agar (Lennette et al., 1974). Antibiotic paper discs (bioMerieux, Charbonnieres-les-Bains, France) containing Ampicillin (10 pg); Streptomycin (10 pg); Tetracycline (30 pg) and Neomycin $(30 \mathrm{pg}$ ) were put on the surface of the inoculated agar and all plates were incubated at $30^{\circ} \mathrm{C}$ for 2 days. Zone of inhibitions were measured as described in the instructions (bioMerieux).

\section{Results ad Discussion}

Caves are found in many types of rocks and are formed by different geological processes. Caves of Somman are formed by dissolving calcareous rocks and slow moving of the groundwater from the passages and cavities (Moore \& Sullivan, 1978). In present study, three caves of the Somman were visited, characterized and microbial diversity of these three was determined. A part of the map of Saudi Arabia showing the three studied caves, north east of Riyadh city was represented in Figure 1. The caves under study named Mossy, Hotel and Reda caves. The three studied caves have interesting pattern, among these first two caves have horizontal and easy to walk while the third one viz, Mossy cave has deep pit, with $4 \mathrm{~m}$ long, and need ropes and a ladder to go inside (Figure 2). Similarly, Amasha (2012) studied, characterized and isolated various bacterial strains from Ghar Al Hibashi cave which is located $300 \mathrm{~km}$ southeast of Makkah, Saudi Arabia $\left(21^{\circ} 10^{\prime} \mathrm{N}, 42^{\circ} 10^{\prime} \mathrm{E}\right)$. Environmental 


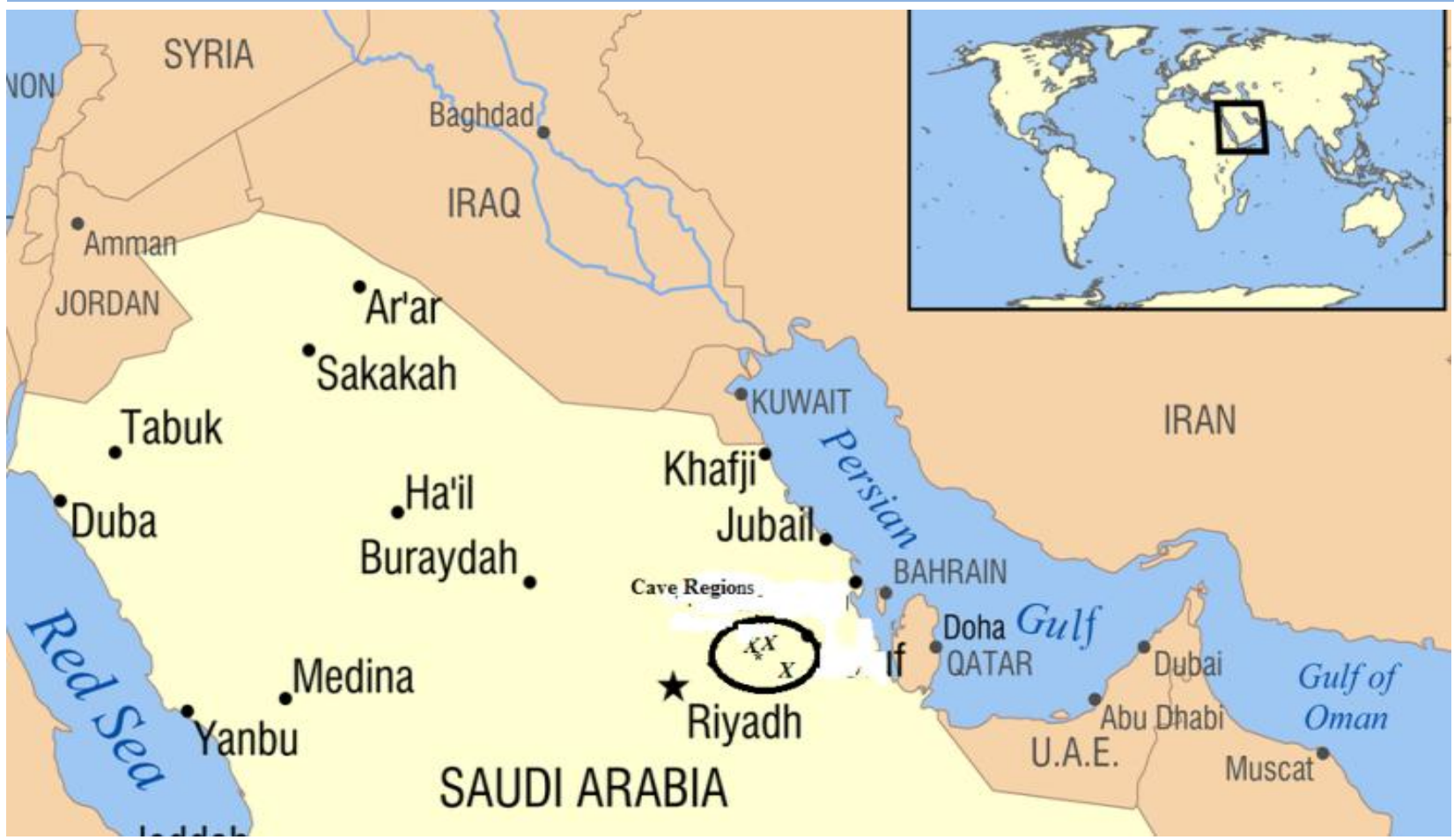

Figure 1 A part of the map of Saudi Arabia showing studied caves, north east of Riyadh city
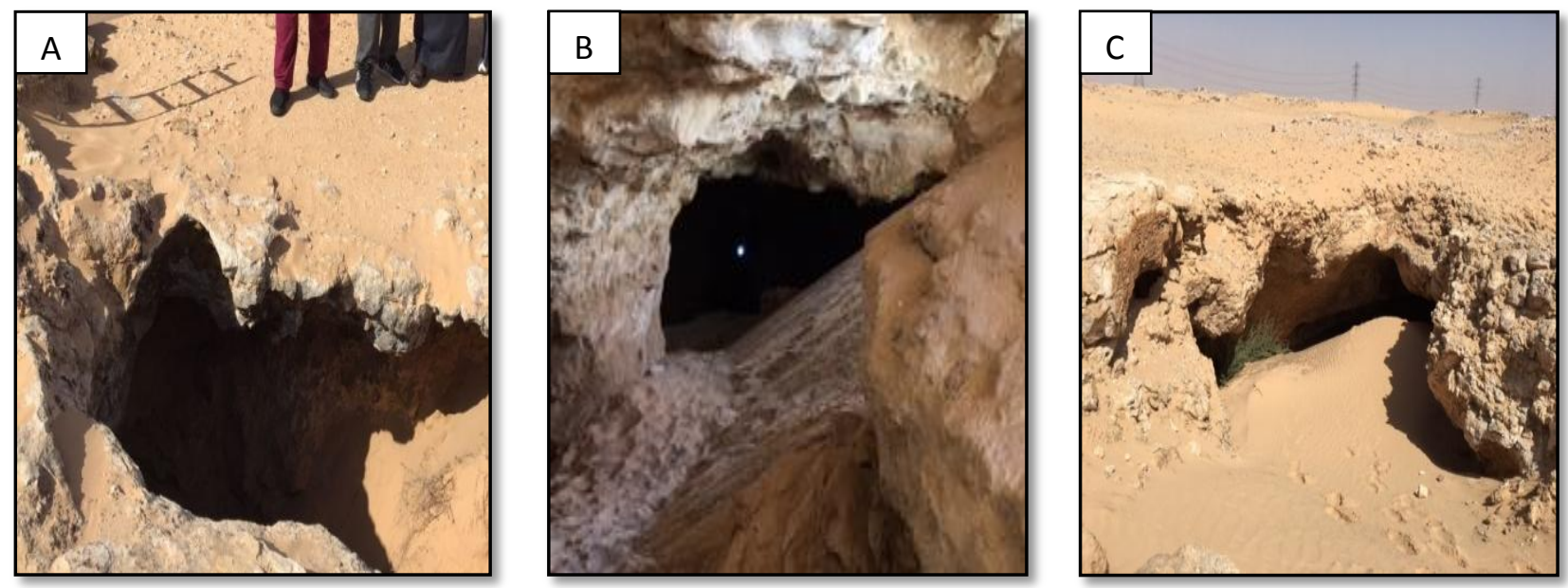

Figure 2 The three studied caves, A: Mosse cave, B: hotel cave, and C: Reda cave, Riyadh, Saudi Arabia

characteristics of the three studied caves and mat colours were determined (Table 2). During study, obtained mat colours (Table 1) were gray, tan, yellow, brown and white. Similarly, tan, white, and yellow colours were reported by Lavoie et al (2017). At the bingeing, dry and wet bulb temperatures $\left({ }^{\circ} \mathrm{C}\right)$ and Barometric pressure (mbar) were measured in January and used to calculate percentage of relative humidity $\mathrm{RH}$ ). During study, cave air temperatures ranged from 29 to $33^{\circ} \mathrm{C}$, while $\mathrm{RH}$ values ranged between $41 \%$ and $53 \%$. Similarly, lower temperature and higher relative humidity was recorded for Torgac cave, New Mexico by Forbes (1998). The contents of $\mathrm{Cd}, \mathrm{Cr}, \mathrm{Co}, \mathrm{Cu}$ and $\mathrm{Fe}$ have been assayed in the cave soils. This area is affected by microorganism growth, thus soil organic carbon content was varied from 0.23 $0.70 \%$. The highest value of organic carbon was reported from the soil collected from Mosse cave. Soil contamination was assessed on the basis of heavy metal concentrations (Table 2) and 
geo-accumulation index (I geo) as in Figure 3. The results revealed elevated contents of I geo for $\mathrm{Cd}$ and $\mathrm{Cr}$. The contents of $\mathrm{Cu}, \mathrm{Fe}$, and $\mathrm{Co}$ were similar to the levels in the Earth's crust (Table 3).

Caves are like underground chambers that contained extremophilic microorganisms which interact directly with the geology of the place and carried different microbial activities, ranged from the obvious slimy growth to the more subtle deposition of calcite or alteration of the rock surface. In caves the microbial activities were shown as surface dots, unusual coloration, biofilm formation and corrosion residues (Barton, 2006). In this study, total counts of bacteria, actinomycetes and fungi were determined for cave walls and soils. Generally, the cave soil contained more microorganisms compared to cave walls and the counts of bacteria were significantly higher, this was followed by fungal counts and actinomycete counts. The highest bacterial counts were recorded from Mosse cave wall and soil. Further, Mosse wall contained $68 \%$ bacteria, $09 \%$ actinomycetes and $25 \%$ fungi while this percentage was $60.5 \%$, $5.5 \%$ and $34 \%$ for Mosse cave soil. Actinobacteria were found in all cave samples in the range of 4$10 \%$ for cave walls and 5.5-8 \% for cave surface soils. The highest actinomycete counts were recorded from soil of Hotel and Reda caves while in case of wall actinomyctes percentage, highest was reported from the wall of Reda cave (10\%) and this was followed by the wall percentage of Mosse cave (9\%). In case of fungal counts, highest fungal count was recorded for soil of Reda (37\%) and Mosse (34\%) caves (Table 4). The commonest bacterial isolates obtained on nutrient agar were selected, purified and identified using morphological, physiological and biochemical characterisation. Identifications were carried out according to Krieg \& Holt (1984), Sneath et al. (1986), Brenner et al. (2005), and Krieg (2015). Further, isolated microorganism identified and characterized by using $16 \mathrm{~S}$ rRNA gene, which is very accurate method for bacterial phylogeny and taxonomy (Michael \& Abbott, 2007). Total eleven bacterial species viz., Alcaligenes faecalis, Bacillus cereus, Bacillus nealsonii, Brevibacterium sp., Klebsiella pneumoniae, Planomicrobium okeanokoites, Shigella flexneri, Pseudomonas earuginosa, Staphylococcus aureus, Staphylococcus epidermidis and Staphylococcus equorum have been
Table 2 Environmental characteristics of the three studied caves and mat colours

\begin{tabular}{|ccccccc|}
$\begin{array}{c}\text { Cave } \\
\text { name }\end{array}$ & $\begin{array}{c}\text { No. of } \\
\text { entrances }\end{array}$ & $\begin{array}{c}\text { Elevation } \\
(\mathrm{m})\end{array}$ & $\begin{array}{c}\text { Distance of } \\
\text { sample from } \\
\text { entrance }(\mathrm{m})\end{array}$ & $\mathrm{pH}$ & $\begin{array}{c}\mathrm{RH} \\
(\%)\end{array}$ & $\begin{array}{c}\text { Mat } \\
\text { colours }\end{array}$ \\
\hline Mosse & 1 & 4.0 & 5.0 & $\mathrm{Nd}$ & 53 & $\begin{array}{c}\text { Gray and } \\
\text { tan }\end{array}$ \\
\hline Hotel & 1 & 2.11 & 3.3 & 7.9 & 41 & $\begin{array}{c}\text { Yellow, } \\
\text { and tan }\end{array}$ \\
\hline Reda & 2 & 1.8 & 2.9 & $\mathrm{Nd}$ & 47 & $\begin{array}{c}\text { Brown } \\
\text { and white }\end{array}$ \\
\hline
\end{tabular}

Nd: Not determined, RH: Relative humidity

Table 3 Total carbon and heavy metal concentrations ( $\mu \mathrm{g} / \mathrm{g}$; dry weight), Cadmium, Chromium, Cobalt, Copper and Iron

\begin{tabular}{|lcccccc|}
\hline $\begin{array}{c}\text { Cave } \\
\text { name }\end{array}$ & $\begin{array}{c}\text { Soil } \\
\text { organic } \\
\text { carbon } \\
\text { content }(\%)\end{array}$ & $\begin{array}{c}\text { Cadmium } \\
(\mathrm{Cd})\end{array}$ & $\begin{array}{c}\text { Chromium } \\
(\mathrm{Cr})\end{array}$ & $\begin{array}{c}\text { Cobalt } \\
(\mathrm{Co})\end{array}$ & $\begin{array}{c}\text { Coppe } \\
\mathrm{r}(\mathrm{Cu})\end{array}$ & $\begin{array}{c}\text { Iron } \\
(\mathrm{Fe})\end{array}$ \\
\hline Mosse & 0.70 & 0.36 & 61.9 & 129 & 57 & 1600 \\
\hline Hotel & 0.23 & 0.25 & 93.3 & 155 & 55 & 1700 \\
\hline Reda & 0.60 & 0.32 & 62.4 & 121 & 75 & 1200 \\
\hline
\end{tabular}

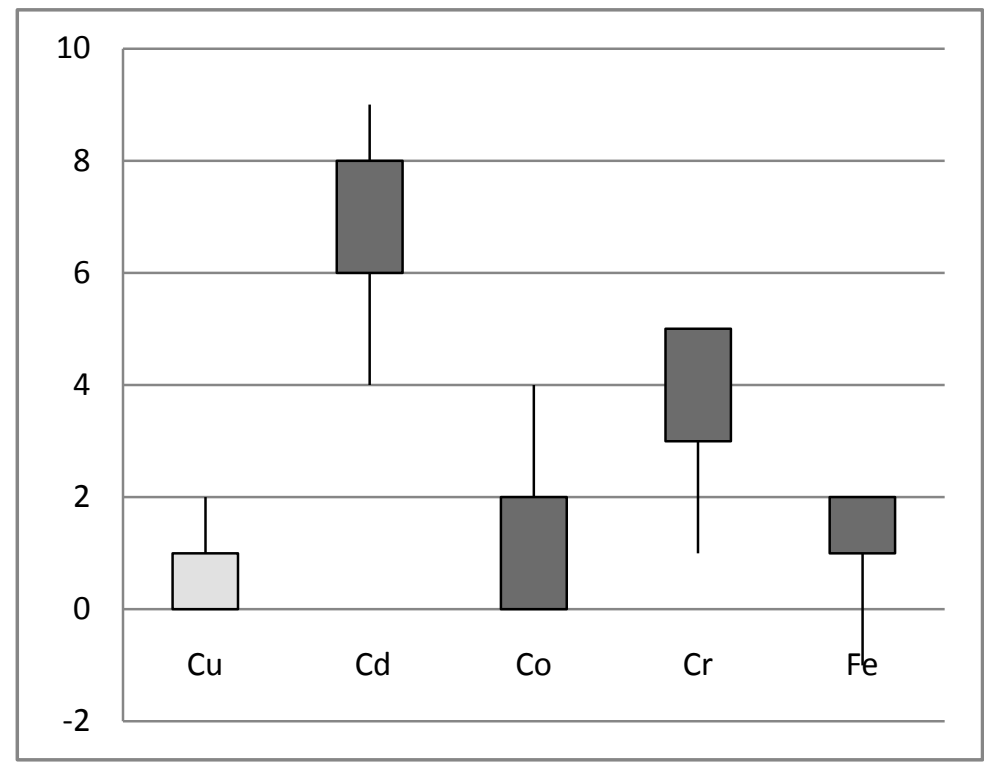

Figure 3 Geoaccumulation index (I geo) for trace metals in the study area I geo < 0 :

Uncontaminated, $2<$ I geo < 3: Mod.-heavy, $4<$ Igeo < 5: Heavy-extreme, $5<$ I geo : Extreme 
Table 4 Total counts (CFU/g) of Bacteria, Actinomycetes and Fungi on agar media and the percentage of occurrence (\%) for cave walls and soils.

\begin{tabular}{|cccccccc} 
Microorganisms & \multicolumn{4}{c}{ Mosse cave } & \multicolumn{2}{c}{ Studied Cave } \\
& Wall & Surface soil & Wall & Surface soil & Red cave & Wall & Surface soil \\
\hline Bacteria & $1.11 \times 10^{4}(68 \%)$ & $1.73 \times 10^{4}(60.5 \%)$ & $\left.1.00 \times 10^{4} 34 \%\right)$ & $1.33 \times 10^{4}(59 \%)$ & $1.03 \times 10^{4}(53 \%)$ & $1.43 \times 10^{4}(55 \%)$ \\
\hline Actinomycetes & $1.04 \times 10^{3}(9 \%)$ & $1.59 \times 10^{3}(5.5 \%)$ & $1.33 \times 10^{3}(4 \%)$ & $1.99 \times 10^{3}(8 \%)$ & $1.99 \times 10^{3}(10 \%)$ & $1.96 \times 10^{3}(8 \%)$ \\
\hline Fungi & $0.37 \times 10^{4}(25 \%)$ & $0.98 \times 10^{4}(34 \%)$ & $0.78 \times 10^{4}(26 \%)$ & $0.77 \times 10^{4}(33 \%)$ & $0.70 \times 10^{4}(37 \%)$ & $0.94 \times 10^{4}(37 \%)$ \\
\hline
\end{tabular}

Table 5 The isolated and identified bacteria, accession numbers and their $\%$ of resistance to heavy metals

\begin{tabular}{|c|c|c|c|c|c|}
\hline Isolated bacteria & Accession number & Gram reaction & \multicolumn{3}{|c|}{$\%$ of Resistance to heavy metal $(1300 \mu \mathrm{g} / \mathrm{ml})$} \\
\hline Alcaligenes faecalis $(\mathrm{n}=17)$ & NR_113606.1 & Negative & 69 & 59 & 49 \\
\hline Bacillus cereus $(\mathrm{n}=29)$ & NR_074540.1 & Positive & 99 & 77 & 75 \\
\hline Bacillus nealsonii $(\mathrm{n}=14)$ & NR_044546.1 & Positive & 56 & 69 & 65 \\
\hline Brevibacterium $(\mathrm{n}=9)$ & NR_115063.1 & Positive & 60 & 59 & 56 \\
\hline Klebsiella pneumoniae $(\mathrm{n}=22)$ & NR_117683.1 & Negative & 55 & 77 & 47 \\
\hline Planomicrobium okeanokoites $(n=14)$ & NR_113593.1 & Positive & 49 & 41 & 60 \\
\hline Shigella flexneri $(\mathrm{n}=17)$ & NR_026331.1 & Negative & 64 & 33 & 31 \\
\hline Pseudomonas earuginosa $(\mathrm{n}=33)$ & CP012001.1 & Negative & 94 & 55 & 69 \\
\hline Staphylococcus aureus $(\mathrm{n}=21)$ & CP011526.1 & Positive & 69 & 29 & 60 \\
\hline Staphylococcus epidermidis $(\mathrm{n}=32)$ & LN681574.1 & Positive & 79 & 41 & 29 \\
\hline Staphylococcus equorum $(n=16)$ & NR_041926.1 & Positive & 89 & 39 & 48 \\
\hline
\end{tabular}

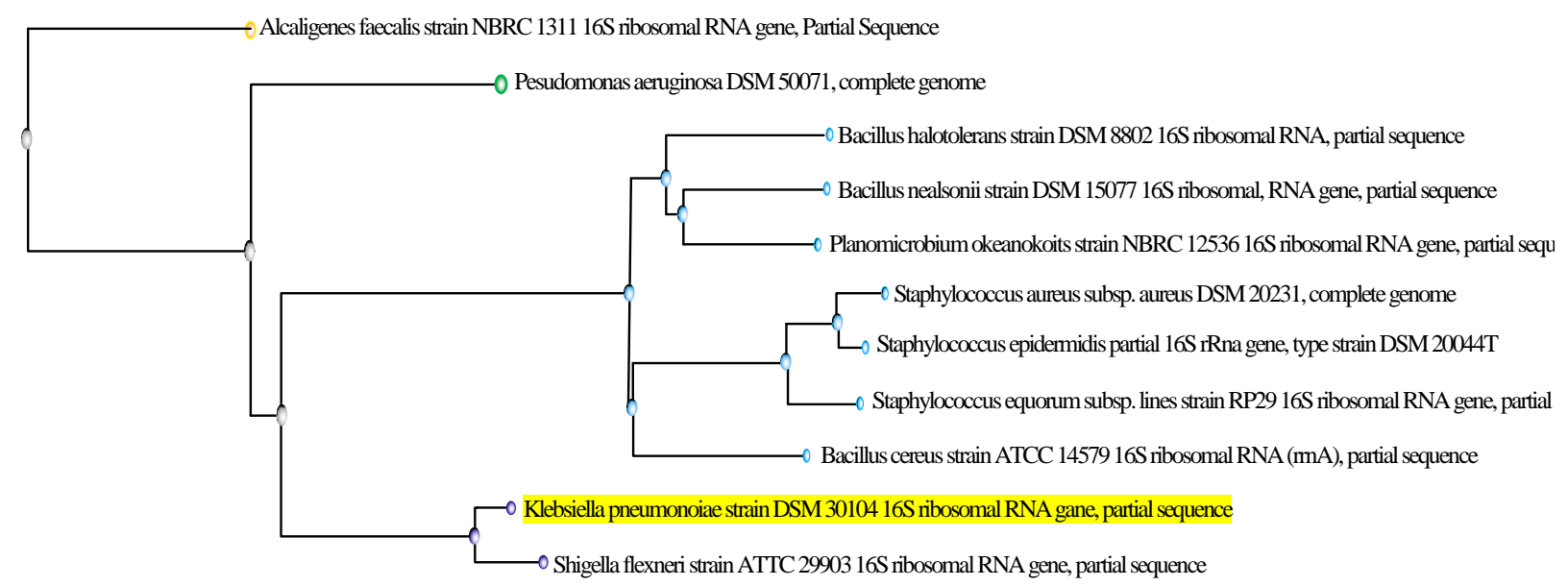

Figure 4 Phylogenetic tree based on 16S rDNA sequence comparisons of 11 identified bacterial isolates, obtained from the tree tested caves, using neighbor joining tree method, maximum sequence difference $=0.002$.

identified (Table 5, Figure 4). Findings of present study are in agreement with the findings of Amasha (2012) who used $16 \mathrm{~S}$ rRNA gene for determining the bacterial diversity of Ghar $\mathrm{Al}$ Hibashi cave of Makkah, result of this study suggest the presence of Bacillus species in higher quantity. Parker Cave, Kentucky received sulphurous water and molecular phylogenetic analysis of the microbial mat revealed the presence of Thiothrix spp., Thiomicrospira denitrificans and Thiobacillus baregensis (Angert 
et al., 1998). Moreover, Oliveira et al. (2017) examined five sites of Ozark region caves and used 16S rRNA genebased metagenomic analysis for bacterial diversity. They reported a variation in bacterial composition, species abundance and diversity among the five caves studied and the lowest richness was found for Sand town cave. Lavoie et al. (2017) studied lava cave microbial diversity of subsurface mats and surface soils using $16 \mathrm{~S}$ rDNA. They noticed the same genera for both surface soils and cave microbial mats and actinobacteria dominated in all cave samples. These results are in agreement with the findings of present study. Microbial diversity of caves was evaluated and further work on cave environments and their microbes are needed (Al'Abri, 2011; Almalki, 2012; Lavoie et al., 2017).

Chemical reactions that cause mineral dissolution and precipitation were regulated by microorganisms which also affect contaminant remediation (Thomas \& Ward, 1992; Engel \& Randall, 2011; Lian et al., 2011). The percentages of resistance in all bacterial isolates against metallic cations or heavy metals such as $\mathrm{Cu}, \mathrm{Cd}$ and $\mathrm{Cr}$ were determined (Table 5). The most resistant isolate was Bacillus cereus where $99 \%$ were resistant to $\mathrm{Cu}, 77 \%$ to $\mathrm{Cd}$ and $75 \%$ to $\mathrm{Cr}$. Moreover, 94 and $69 \%$ of Pseudomonas earuginosa isolate were resistant to $\mathrm{Cu}$ and $\mathrm{Cr}$, respectively while $77 \%$ of the isolates of Klebsiella pneumoniae were resistant to $\mathrm{Cd}$ (Figure 5). From the contaminated area, two bacterial isolates, Gemella $\mathrm{sp}$. and Micrococcus sp., which were identified based on morphological, cultural, physiological and biochemical characteristics, showed resistance against Lead, chromium and cadmium (Marzan et al., 2017). Although the tested cave bacteria have not exposed to anthropogenic antibiotics before, isolates of Pseudomonas earuginosa were the most resistance to all tested antibiotics; percentages of resistance were $91,64,54$ and $43 \%$ for Ampicillin, Streptomycin, Tetracycline and Neomycin respectively. Percentages of resistances in Klebsiella pneumoniae isolate were 81 and $55 \%$ for Ampicillin and Streptomycin while the resistance of Staphylococcus aureus isolate was 63 and $44 \%$ for Tetracycline and Neomycin, respectively (Table 6). Studying the resistance of bacterial isolates that are not exposed to antibiotics before is very interesting. The decrease in annual detection rates of Staphylococcus aureus and their increases in cases of $P$. aeruginosa and Klebsiella pneumoniae were recorded by Dou et al. (2017). Various factors are responsible for the bacterial resistance, among these some common are target modification, drug influx and efflux control, and presence of inactivation enzymes which are found due to

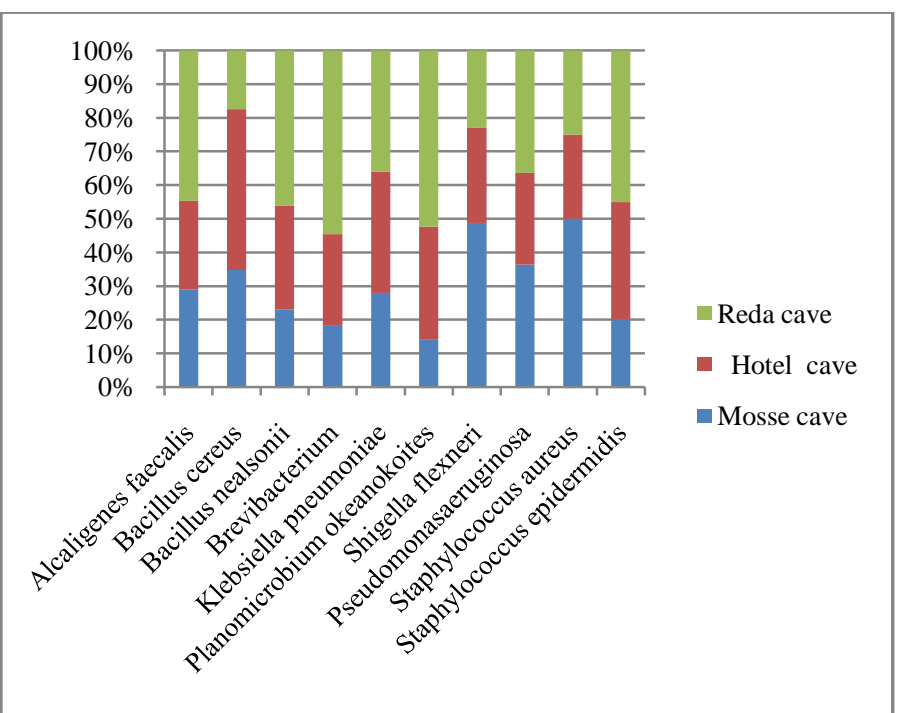

Figure 5 Percentage of occurrence of the isolated and identified bacteria in the three studied caves

Table 6 Percentage of resistance of the isolated bacteria from caves to different antibiotics

\begin{tabular}{|lcccc|}
\hline \multicolumn{5}{|c|}{$\%$ of resistance to antibiotics } \\
Tested bacteria & $\begin{array}{l}\text { Ampicillin } \\
(10 \mathrm{pg})\end{array}$ & $\begin{array}{l}\text { Streptomycin } \\
(10 \mathrm{pg})\end{array}$ & $\begin{array}{l}\text { Tetracycline } \\
(30 \mathrm{pg})\end{array}$ & $\begin{array}{l}\text { Neomycin } \\
(30 \mathrm{pg})\end{array}$ \\
\hline $\begin{array}{l}\text { Alcaligenes faecalis } \\
(\mathrm{n}=17)\end{array}$ & 67 & 56 & 33 & 12 \\
\hline $\begin{array}{l}\text { Bacillus cereus } \\
(\mathrm{n}=29)\end{array}$ & 33 & 33 & 49 & 35 \\
\hline $\begin{array}{l}\text { Bacillus nealsonii } \\
\text { (n=14) }\end{array}$ & 49 & 31 & 51 & 29 \\
\hline $\begin{array}{l}\text { Brevibacterium } \\
(\mathrm{n}=9)\end{array}$ & 77 & 19 & 41 & 33 \\
\hline $\begin{array}{l}\text { Klebsiella } \\
\text { pneumoniae }(\mathrm{n}=22)\end{array}$ & 81 & 55 & 33 & 28 \\
\hline $\begin{array}{l}\text { Planomicrobium } \\
\text { okeanokoites }(\mathrm{n}=14)\end{array}$ & 66 & 54 & 30 & 33 \\
\hline $\begin{array}{l}\text { Shigella flexneri } \\
\text { (n=17) }\end{array}$ & 32 & 39 & 39 & 28 \\
\hline $\begin{array}{l}\text { Pseudomonas } \\
\text { earuginosa }(\mathrm{n}=33)\end{array}$ & 91 & 64 & 54 & 43 \\
\hline $\begin{array}{l}\text { Staphylococcus } \\
\text { aureus }(\mathrm{n}=21)\end{array}$ & 70 & 51 & 63 & 28 \\
\hline $\begin{array}{l}\text { Staphylococcus } \\
\text { epidermidis }(\mathrm{n}=32)\end{array}$ & 46 & 29 & 51 & 43 \\
\hline $\begin{array}{l}\text { Staphylococcus } \\
\text { equorum }(\mathrm{n}=16)\end{array}$ & 17 & 46 & 28 & 28 \\
\hline
\end{tabular}


evolution and natural selection. Non-pathogenic bacteria may act as resistant gene reservoirs which may be transferred to the harmful bacteria (Allen et al., 2009, Donato et al., 2010). The outstanding ecosystem, Lechuguilla cave, was found over 4 million years and is a best biosystem to study bacterial resistant. From Lechuguilla cave, 93 bacterial strains, live under limited nutrient environment, were isolated and surveyed for antibiotic susceptibility and most of these isolates were considered as multidrug resistant. Antibiotic resistant bacteria are common in cave environments (Bhullar et al., 2012). Bacterial resistance patterns to many antibiotics were different and more studies of cave microbiota including extensive cultivation and metagenomic analysis are needed.

\section{Acknowledgements}

This Project was funded by the Deanship of Scientific Research (DSR), King Abdulaziz University, Jeddah, under grant No (J1436- 130- 609). The authors, therefore, acknowledges with thanks DSR technical and financial support. Thanks also for Prof. Magda M. Aly for helping in sample collections and reviewing of the manuscript.

\section{Conflict of Interest}

Authors would hereby like to declare that there is no conflict of interests that could possibly arise

\section{References}

Al'Abri K (2011) Use of Molecular Approaches to Study The Occurrence of Extremophiles and Extremodures in Non-Extreme Environments. $\mathrm{PhD}$ Thesis Submitted to the University of Sheffield, UK.

Allen HK, Cloud-Hansen KA, Wolinski JM, Guan C, Greene S, Boeyink M, Broderick A, Raffa K, Hadelsaman J (2009) Resident microbiota of the gypsy moth midgut harbors antibiotic resistance determinants. DNA Cell Biology 28: 109-117.

Almalki M (2012) Molecular Identification and Characterisation of Acid Tolerant Microorganisms Isolated from Rivelin and Limb Valleys. PhD Thesis submitted to the University of Sheffield, UK.

Al-Shanti MA, Pint JJ, Al-Juaid AJ, Al-Amoudi SA (2003) Preliminary survey for caves in the Habakah region of the Kingdom of Saudi Arabia: Saudi Geological Survey Open-File report SGS-OF-2003-3,Pp. 32.

Amann RI, Snaidr J, Wagner M, Ludwig W, Schleifer KH (1996) In situ visualization of high genetic diversity in a natural community. Journal of Bacteriology 178: 3496-3500.
Amasha R (2012) Studies on the Environmental Microbiology and Biogeochemistry of Desert Surface Soils. PhD Thesis submitted to the University of Sheffield, UK.

Angert ER, Northup DE, Reysenbach AL, Peek AS, Goebel BM, Pace NR (1998) Molecular phylogenetic analysis of a bacterial community in Sulphur River, Parker Cave, Kentucky. American Mineralogist 83:1583-1592.

Barton HA (2006) Introduction to cave microbiology: A review for the non-specialist. Journal of Cave and Karst Studies 68:4354.

Barton HA, Luiszer F (2005) Microbial Metabolic Structure in a Sulfidic Cave Hot Spring: Potential Mechanisms of Biospeleogenesis: Journal of Cave and Karst Studies 67:28-38.

Bhullar K, Waglechner N, Pawlowski A, Koteva K, Banks ED, Barton HA, Wright JD (2012) Antibiotic resistance is prevalent in an isolated cave microbiome. PLOS ONE 7: e34953. doi:10.1371/journal.pone.0034953.

Brenner DJ, Krieg NR, Staley JT (2005) The Gammaproteo bacteria (Williams \& Wilkins)]. In: Garrity GM. (Ed.) Bergey's Manual of Systematic Bacteriology, 2B (2nd ed.). New York: Springer. Pp. 1108.

Clermont O, Bonacorsi S, Bingen E (2000) Rapid and simple determination of the Escherichia coli phylogenetic group. Applied and Environmental Microbiology 66:10 4555-4558.

Donato JJ, Moe LA, Converse BJ, Smart KD, Berklein FC, McManus PS, Hadelsman J (2010) Metagenomics Reveals Antibiotic Resistance Genes Encoding Predicted Bifunctional Proteins in Apple Orchard Soil. Applied and Environtal Microbiology 76:4396-4401.

Donkin M (1991) Loss on ignition as an estimator of soil organic carbon in a horizon forestry soils. Communications in Soil Science \& Plant Analysis 22: 233-241.

Dou Y, Huan J, Guo F, Zhou Z, Shi Y (2017) Pseudomonas aeruginosa prevalence, antibiotic resistance and antimicrobial use in Chinese burn wards from 2007 to 2014. Journal of International Medical Research 45:1124-1137.

du Preez G, Wepener V, Dennis I (2016) Ingrid Metal enrichment and contamination in a karst cave associated with anthropogenic activities in the Witwatersrand Basin, South Africa. Environment Earth Science 75: 653. https://doi.org/10.1007/s12665-016-5455-2.

Engel AS, Randall KW (2011) Experimental evidence for microbially mediated carbonate dissolution from the saline water 
zone of the Edwards Aquifer, Central Texas. Geomicrobiology Journal 28: 313-327.

Finegold SM, Martin WJ (Ed.) (1982) Standardized disc agar diffusion method for determining susceptibility to antibiotics. In Diagnostic Microbiology, London: CV Mosby Co. Pp. 542-550.

Forbes J (1998) Air Temperature and Relative Humidity Study: Torgac Cave, New Mexico. Journal of Cave and Karst Studies 60: 27-32.

Forti P, Pint JJ, Al-Shanti MA, Al-Juaid AJ, Al-Amoudi SA, Pint SI (2003) The development of touristcaves in the Kingdom of Saudi Arabia, Saudi Geological Survey Open-File Report SGSOF-2003-6, Pp. 32.

Hathaway JJM (2010) Molecular Phylogenetic Investigation of Microbial Diversity and Nitrogen Cycling in Lava Tubes. Masters Thesis submitted to the University of New Mexico, Mexico.

Hotzl H, Maurin V, Zotl JG (1978) Geologic history of the Al Hasa area since Pliocene. In: Al-Sayari SS, Zotl JG (Eds.) Quaternary Period in Saudi Arabia., Springer-Verlag, Pp. 58-67.

Hussain M, Al-Khalifah F, Khandaker NI (2006) The Jabal Al Qarah Caves of the Hofuf Area, Northeastern Saudi Arabia: A geological investigation. Journal of Cave and Karst Studies 68:12-21.

Ji Y, Feng Y, Wu J, Zhu T, Bai Z, Duan C (2008) Using geoaccumulation index to study source profiles of soil dust in China. Journal of Environmental Sciences 20: 571-578.

Krieg NR (2015) Identification of Procaryotes . Bergey's Manual of Systematics of Archaea and Bacteria, Pp. 1-8.

Krieg NR, Holt JC (Eds.) (1984) Bergey's Manual of Systematic Bacteriology, 1st ed., vol. 1, Williams and Wilkins, Baltimore.

Laker MC, Du Preez CC (1982) An investigation into the accuracy of hydrometers for soil particle size determination. Agroplantae 14: 17-22.

Lavoie KH, Winter AS, Read KJH, Hughes EM, Spilde MN, Northup DE (2017) Comparison of bacterial communities from lava cave microbial mats to overlying surface soils from Lava Beds National Monument, USA. PLoS ONE 12: e0169339. doi:10.1371/journal.pone.0169339.

Lennette EH, Spaulding EH, Truant JP (Ed) (1974) Manual of Clinical Microbiology. Washington, DC: American Society for Microbiology.
Lian B, Yuan D, Liu Z (2011) Effect of microbes on karstification in karst ecosystems. Chinese Science Bulletin 56: 3743-3747. doi: 10.1007/s11434-011-4648-Z.

Loska K, Wiechuła D, Korus I (2004) Metal contamination of farming soils affected by industry. Environment International 30: 159-165.

Madigan MT, Martinko JM, Parker J (2000) Brock Biology of Microorganism. 8th Edn., Prentice Hall, Upper Saddle River, Pp: 891-921.

Marzan L, Hossain M, Mina SA, Akter Y, Chowdhury AM (2017) Isolation and biochemical characterization of heavy-metal resistant bacteria from tannery effluent in Chittagong city, Bangladesh: Bioremediation viewpoint. Egyptian Journal of Aquatic Research 43: 65-74.

Michael J, Abbott SL (2007) 16S rRNA Gene Sequencing for Bacterial Identification in the Diagnostic Laboratory: Pluses, Perils, and Pitfalls. Journal of Clinical Microbiology 45:27612764.

Moore GW, Sullivan GN (1978) Speleology-The Study of Caves: Zephyrus Press, Teaneck, New Jersey, 2nd edition, Pp.150.

Muller G (1969) Index of geoaccumulation in sediments of the Rhine River. GeoJournal 2:108-118.

Oliveira C, Gunderman L, Coles CA, Lochmann J, Parks M, Ballard E, Glazko G, Rahmatallah Y, Tackett AJ, Thomas DJ (2017) 16S rRNA Gene-Based Metagenomic Analysis of Ozark Cave Bacteria. Diversity 9: 31; doi:10.3390/d9030031.

Pint JJ (2009) The Lava Caves of Khaybar, Saudi Arabia. Published in Proceedings, 15th International Congress of Speleology, July 2009, Kerrville, Texas, Pp. 1873-1878.

Pint JJ (2006) Vulcanospeleology in Saudi Arabia. Acta Carsologica 35: 107-119.

Plotnikova AO, Kornevab JV, Izvekovab GI (2010) Morphological and Physiological Characteristics of Bacteria Inhabiting the Intestinal Mucosa of Pike (Esox lucius L.). Inland Water Biology 3:173-180.

Pridham TG, Anderson P, Foley C, Lindenfelser LA, Hesselting CW, Benedict RG (1957) A section of media for maintenance and taxonomic study of Streptomycetes. Antibiotics Annul Journal, 947-953.

Shivaji S, Reddy GS, Raghavan PU, Sarita NB, Delille D (2004) Psychrobacter salsus sp. nov. and Psychrobacter adeliensis sp. 
nov. isolated from fast ice from Adelie Land, Antarctica. Systematic and Applied Microbiology 27:628-635.

Sneath PHA, Mair NS, Sharpe ME, Holt JG (Eds.) (1986) Bergey's Manual of Systematic Bacteriology, 1st ed., vol. 2, Williams \& Wilkins, Baltimore.

Sonneveld C, Van Den Ende J (1971) Soil analysis by means of a 1:2 volume extract. Plant and Soil 35: 505-516.
Thomas JM, Ward CH (1992) Subsurface microbial ecology and bioremediation. Journal Hazardous Material 32, 179-194.

Washington JA, Sutter VL (1980) Dilution susceptibility test: agar and macro-broth dilution procedures. In: Lennette EH, Balows A, Hauler WJ, Truant JP (Eds) Manual of Clinical Microbiology, $3^{\text {rd }}$ ed. Washington, DC: -American Society for Microbiology pp. 453458. 